Swarthmore College

Works

2016

\title{
A History Of Inherent Contradictions: The Origins And End Of American Conservatism
}

James Kurth

Swarthmore College, jkurth1@swarthmore.edu

Follow this and additional works at: https://works.swarthmore.edu/fac-poli-sci

Part of the Political Science Commons

Let us know how access to these works benefits you

\section{Recommended Citation}

James Kurth. (2016). "A History Of Inherent Contradictions: The Origins And End Of American Conservatism". American Conservativism. Volume 56, 13-54.

https://works.swarthmore.edu/fac-poli-sci/650

This work is brought to you for free by Swarthmore College Libraries' Works. It has been accepted for inclusion in Political Science Faculty Works by an authorized administrator of Works. For more information, please contact myworks@swarthmore.edu. 


\title{
A HISTORY OF INHERENT CONTRADICTIONS: THE ORIGINS AND END OF AMERICAN CONSERVATISM
}

\author{
JAMES R. KURTH
}

It has long been understood that there is something peculiar, even paradoxical, about conservatism in America. American conservatism is different from conservatism in other countries, even those that were the original source of many other American ideas and ideals, the countries of Europe. Indeed, the very term "American conservatism" is something of an oxymoron. For most Europeans who came to America, the whole purpose of their difficult and disruptive journey to the New World was not to conserve European institutions but to leave them behind and to create something new, often an entirely new life, and even a new identity, for themselves.

In this chapter, I will examine how the paradoxes of American conservatism have unfolded and revealed themselves in the course of American history. In many respects, the history of American conservatism has been the working out of certain inherent contradictions and fatal flaws, beginning with the origins of a distinctive and peculiar kind of conservatism in eighteenth-century America, through its full development during the nineteenth and early twentieth centuries, to the great debacle of this original American conservatism during the Great Depression of the 1930s, to the reinvention and transformation of American conservatism 
during the Great Stagflation of the 1970s, and finally to the recent debacle of this reinvented conservatism during the Great Recession, which began in 2007 and which continues into the 2010s. I will conclude with a review of the current condition of what now passes for American conservatism.

\section{The Three Dimensions of American Conservatism}

In recent decades, political analysts have found it useful to interpret American political movements by distinguishing between different policy dimensions or arenas. Thus, conservatives have been divided into: (1) those who are most concerned about economic or fiscal issues, that is, pro-business or "free-enterprise" conservatives; (2) those most concerned with religious or social issues, that is, pro-church or "traditional-values" conservatives; and (3) those most concerned with national-security or defense issues, that is, pro-military or "patriotic" conservatives.

These three arenas are not of equal weight and strength in the conservative movement, however. It is the business elite that, in the long course of American history, has proven to be the most powerful component of the conservative coalition; it has gotten its way on more issues than either the religious or the security conservatives, and it has done so not only within the conservative coalition itself, but also with actual government policies. Calvin Coolidge may have exaggerated somewhat when, in the 1920s, he said that "the business of America is business," but it has been no exaggeration that the business of American conservatism has been business.

It was the achievement of Ronald Reagan that he was able in the late 1970s to unite these three different kinds of conservatism into one grand coalition. This was the culmination of a "fusionist strategy" that had been developing amongst American conservatives since the early 1960s. ${ }^{1}$ For a while, especially during the 1980s, it may have seemed that these three kinds of conservatives were natural allies, that they had an "elective affinity" for each other, and that there was no significant contradiction between them. However, as we shall see, pro-business conservatism has always included a tendency toward the disruption and even dissolution of religious ideals and social practices. This is the famous "cultural contradictions of capitalism," identified by social theorists 
as varied as Karl Marx, Joseph Schumpeter, and Daniel Bell. ${ }^{2}$ And in recent decades, pro-business conservatism has also included a tendency toward the dismantling of national boundaries and even dissolution of national identities, and therefore the redefinition of national security. This is the famous "globalization" project of American multinational corporations and financial institutions. ${ }^{3}$ It took about two decades for the fusionist strategy to put together the Reagan grand coalition, and then, about two decades after Reagan's departure, that grand coalition began to fall apart.

\section{Economic Conservatism}

In Europe, economic conditions had been shaped by an established landed class and a highly restricted market in land and labor. In America, economic conditions were instead shaped by an open market in land and labor, and this was reinforced and energized by the open Western frontier. The Industrial Revolution of course greatly diminished the relative importance of landed wealth in the economy, but in Europe the traditional idea of an established economic order-supported by the state and by intimate connections between property owners and government officials, between the wealthy and the powerful-was carried over into the new industrial economy (and, to some extent, even into the postindustrial or information-age economy of our own time). Conversely, in America, the idea of an open market was carried over into the new industrial economy (and even into the post-industrial or information-age economy as well). The long-standing American condition of an open market in just about every economic sector meant that there normally was not an established economic order to conserve. If something were going to be conserved, it would normally be the open market or "free-enterprise" system itself. But the idea of free enterprise was a central pillar of the ideology of European, and classical, liberalism, not of European conservatism. This meant that in America conservatism was committed to conserving liberalism, or at least a central pillar of it. ${ }^{4}$

Thus, the Federalists, the Whigs, and the Republicans have successively been considered to be the more conservative political party within the United States, but each of these has also successively been the most pro-business and free-enterprise party. Since 
business or capitalism is actually one of the most unsettling, even revolutionary, forces the world has ever seen, this means that the conservative party in America has always sought to conserve a revolutionary force. This revolutionary business or capitalist force not only disrupts and destroys existing economic arrangements (Schumpeter's "creative destruction"). It destroys religious, social, and ultimately moral arrangements as well. This means that when religious and social conservatives make an alliance with economic "conservatives" (who are really economic or "classical" liberals, or even libertarians), they are making an alliance with a force that will often choose to betray them. And since the business conservatives are the senior partner within the conservative coalition and the religious and social conservatives are a junior partner, these latter conservatives will be betrayed, and marginalized, again and again.

\section{Religious Conservatism}

In a pattern similar to that of economic conservatism, in Europe an established state church shaped religious and moral conditions. In America, particularly after the adoption of the U.S. Constitution, religious and moral conditions were instead shaped by the separation of church and state and even by religious pluralism. There was early on a competition between different denominations within the dominant Protestant religion. These competing Protestant denominations were soon joined by the Roman Catholic Church, which itself included a variety of ethnicity-based parishes, and by the Jewish community, which included a variety of congregations with differing views on the relationship between tradition and modernity. Indeed, with all of these competing religious teachings and practices, there soon developed something of an open market in religious ideas and institutions, comparable and parallel to the open market in land and labor-and this too was reinforced and energized by the open Western frontier.

This open market in religious matters, so nicely isomorphic with the open market in economic matters, was a powerful factor generating both a reality and an ideology of free choice in the United States. ${ }^{5}$ But another factor lay in the fact that the founding and dominant religion in the United States was Protestantism, rather than some other religion (such as Roman Catholicism or Eastern 
Orthodoxy). In its very origins as a distinct religion, Protestantism "protested" the established religion of Catholicism and thereby promoted the idea of some measure of free choice. ${ }^{6}$ However, in Europe that choice was mostly the choice of a monarch (especially in the Lutheran or Anglican countries) or of an oligarchy (especially in the Calvinist or Reformed countries). It definitely was not the free choice of ordinary individuals. These European patterns were reproduced in the original European settlements in America, with colonies that were directly ruled by appointed representatives of the British monarch being Anglican (for example, Virginia) and colonies that were ruled by local oligarchies being Reformed (such as Massachusetts).

With the American Revolution and then with the U.S. Constitution, however, the forces supporting established state churches fell away. New denominations, particularly Methodists and Baptists, rose up, especially during the Second Great Awakening (1800s to $1820 \mathrm{~s})$, and these denominations very much emphasized the freedom of choice of the individual believer. It is not an accident that the democratic revolution of the Andrew Jackson era of the 1830s was especially robust in those regions of the United States where the Second Great Awakening, Methodists, and Baptists had been especially robust only a decade or two before. Thus, the religious revolution brought by the Second Great Awakening and the democratic revolution brought by the Jackson era greatly reinforced and amplified the religious pluralism, open market, and individual choice that had already begun to characterize the United States. This meant that there was no longer an established religion-and eventually no longer even an established morality and culture-to conserve. If something were going to be conserved, it would be the religious open-market ("free exercise of religion") system. Again, this idea of free exercise of religion was a central pillar of the ideology of European liberalism, not of European conservatism. This meant that in America conservatism was again committed to conserving liberalism, or at least a central pillar of it.

It was thus in the nature of American Protestants that many of them would be inclined to protest this or that religious doctrine or practice and therefore to separate and form new churches or even new denominations. Conservatism in matters of religion was often merely the stance that the older Protestant churches took 
when they had become the target of all this protesting and separating. Since these churches were continually being left behind, religious conservatism was associated with once-dominant churches that were now dwindling into a minority, and would later dwindle into marginality.

However, there eventually came a time when all Protestants, both old churches and new ones, had something substantial to conserve, and this was Protestantism itself, in the face of the challenges posed by the new religious communities that were coming to America. This began with the arrival of masses of Irish Catholic immigrants in the 1840s, shortly followed by the arrival of far smaller, but still significant, numbers of German Jewish immigrants in the $1850 \mathrm{~s}$. Now, all Protestants had something to conserve, at least whatever it was that they held in common that was not Catholic or Jewish.

Various Protestants in various regions and localities did use economic and social institutions to contain the advances of nonProtestants. But Protestants faced serious problems when they tried to use political institutions, including political parties, for the same purpose. By the 1850s, the separation of church and state was very far advanced in the United States, and there was no longer much of a legal basis for excluding non-Protestants from government institutions. Protestant conservatism was contradicted by what had by now become Constitutional conservatism.

The religious-and more broadly, the moral and social-conservatives in America have not been consistently aligned with one political party (such as the Republican Party). In this respect, the religious arena has been somewhat different than the economic one. In particular, the Democratic Party from the 1890s to the 1920s represented many fundamentalist Protestants in the South and in the West, most obviously when William Jennings Bryan was the party's presidential candidate in three elections. Overall, however, the Republican Party has represented the Protestant part of the American population more consistently than has the Democratic Party, with the Democrats being quicker and more effective in reaching out to assist and incorporate new immigrant groups, which were bringing new religions into the United States (as examples, first Catholics and then Jews). 


\section{The Subordination of Religious Conservatism to Economic Conservatism}

One of the most powerful contradictions at work within American conservatism has been the different interests and perspectives of the Protestant conservatives versus those of the economic or business conservatives. In their religious identity, most Americans in the nineteenth and early twentieth centuries may have wanted to conserve some sort of Protestant morality and culture. But in their economic identity, many of these same Americans benefited from the admission of new immigrants, even if these were Catholic or Jewish. Businessmen in particular have always wanted cheaper labor, and new immigrants have always facilitated this. From a business perspective, considerations about the immigrants' religion and culture are distinctly secondary (or even lower) in importance. Even ordinary middle-class Protestants benefited from cheaper labor, in the form of domestic servants. And of course it was the businessmen and middle-class Protestants who controlled the political parties, particularly that party which was supposed to be the more conservative one, first the Whigs and later the Republicans. Thus, the party elites-who benefited from free and open immigration-continually overrode the pro-Protestant and antiimmigrant wishes of many working-class voters. Initially, these voters tried to form new political parties (the Know-Nothings in the 1840s and 1850s and the Populists in the 1880s and 1890s), but these parties were soon co-opted and then subordinated by the major political parties dominated by pro-immigration business and middle-class elites. It was not until these elites themselves turned against immigration, that is, when business interests were temporarily overridden by security ones (during the Red Scare of the late 1910s through the early 1920s), that serious restrictions on immigration were enacted (such as the Immigration Act of 1924).

\section{Security Conservatism}

The similar dynamics that have been at work in economic conservatism and religious conservatism also have had a parallel dynamic at work in the third dimension of American conservatism, that 
of security conservatism. This is the conservatism that puts special emphasis on issues of military policy, national security, and at times patriotic or national identity.

In European countries (with the partial exception of Britain), security conditions were shaped by threats from foreign armies existing on all sides and in close proximity. This gave rise to strong centralized states possessing and deploying large standing armies-a state-army complex-or what might be termed an established security system, parallel to the established landed classes and the established state churches that we have already noted. In America, as the Founders recognized, security conditions were instead shaped by the United States being separated from other great powers by oceans and by having neighbors who were relatively weak. George Washington nicely articulated this concept in his famous Farewell Address in 1796:

The great rule of conduct for us in regard to foreign nations is in extending our commercial relations, to have with them as little political connection as possible. . . Europe has a set of primary interests which to us have none; or a very remote relation. ... Our detached and distant situation invites and enables us to pursue a different course. If we remain one people under an efficient government, the period is not far off when we may defy material injury from external annoyance ... when belligerent nations, under the impossibility of making acquisitions upon us, will not lightly hazard the giving us provocation; when we may choose peace or war, as our interest, guided by justice, shall counsel. Why forego the advantages of so peculiar a situation? Why quit our own to stand upon foreign ground? Why, by interweaving our destiny with that of any part of Europe, entangle our peace and prosperity in the toils of European ambition, rivalship, interest, humor, or caprice? It is our true policy to steer clear of permanent alliances with any portion of the foreign world. ${ }^{7}$

The result of "the advantages of so peculiar a situation" was not exactly parallel to the open markets in the economic and religious arenas (an open market in security is difficult to imagine), but normally there was an absence of military conscription (and therefore a high degree of individual free choice with respect to security issues) and an absence of heavy taxation to support a large military establishment. And even though the Western frontier represented 
a zone of violence and insecurity for much of the nineteenth century, the very weakness of the Indian tribes or "nations" (as they were called by the federal government at the time) compared with the strength of the European nation-states, meant that the actual conditions of the Western frontier reinforced the general sense within the United States of an unthreatening security environment and of individual free choice in security affairs. This long-standing American condition of security meant that there was not an established security system to conserve. If something were going to be conserved, it would normally be the no-conscription and low-taxation (and free-choice) system. But the ideas of no conscription, low taxation, and free choice combined into yet another central pillar of the ideology of European liberalism, not of European conservatism. This meant that in America conservatism was once again committed to conserving liberalism, or at least a central pillar of it.

\section{The Subordination of Segurity Conservatism to Economic Conservatism}

The industrial revolution and more recently the information revolution have been propelled by successive developments in technologies, particularly those that have enabled improvements in transportation and communication-in the ability to move people, goods, and ideas faster and farther. These new technologies obviously provided great profit-making opportunities for new business enterprises that could provide the faster and farther transportation and communication services. But they also provided old business enterprises with new and much larger arenas in which to operate and profit. This meant that each new improvement in transportation and communication technologies expanded the profit-making area beyond the territorial borders of the existing political and governmental units.

Thus, the railroad and the telegraph in the mid-nineteenth century and the automobile, telephone, and radio in the early twentieth century enabled business enterprises to reach (and to push beyond) the borders of any particular American state. Indeed, with these technologies, the most efficient operating and profitmaking area had become the territory of the United States, of the 
American nation, as a whole. Business firms soon left behind any identification-be it practical, ideological, or sentimental-with the particular state in which they had been founded and incorporated, and they sought to expand to at least the territorial borders of the United States. These enterprises became a relentless and often ruthless force hollowing out the powers of the particular states and transferring these powers to the national government (or, when extinguishing these powers altogether, to no government at all).

For about a century (from the 1850s to the 1950s), the dominant transportation and communication technologies (the railroad, telegraph, automobile, telephone, and radio) reinforced national identity and a nationalist ideology over alternative identities and ideologies, in particular smaller or state ones and larger or international ones. This meant that people who thought of themselves as American patriots or nationalists, and who sought to conserve the American nation and to promote American national interests (as they understood these to be), had a ready and powerful ally in business conservatives. During this era, these two kinds of conservatives came together within the Republican Party. In particular, both nationalist and business conservatives could support protectionism with respect to international trade policy. But once business (especially the bigger businesses) could make more money in the international or even global arena than in the national one, the business conservatives would betray the nationalist conservatives.

For a time this conflict within the Republican Party between a nationalist ideology and an international market was masked by an imperialist ideology-the American nation was simply expressing and fulfilling itself within an expanded, extraterritorial area. But after the debacles of the various European and Japanese imperialisms during and after the Second World War, the imperialist ideology could no longer be legitimate in the United States. Business instead supported an internationalist ideology and eventually a full-blown globalist one. Today, there still remain many American patriots or nationalists, but they are not found among the big businesses and the pillars of great wealth. The nationalist version of American conservatism, like the religious version, has been betrayed and marginalized, and it is now largely found only among small businesses and industrial workers. 
The principal reason for this post-national development lies in the same technological process that earlier brought about national development. During the past half-century, new transportation and communication technologies have ushered in new ideas about which political and governmental units provide the best territorial scope for business operations. Thus, the jet airplane and telecommunications, and more recently the computer and the Internet, have enabled businesses to reach and to push beyond the boundaries of particular nation-states-even one as large as the United States-and now the most efficient operating and profit-making area is the globe itself. Business firms soon left behind any identification-be it practical, ideological, or sentimental-with the nation-state in which they were founded and incorporated, and they sought to expand to the very ends of the earth. This was true even with the United States itself, which has provided American multinational corporations and banks with so much support in their negotiations with foreign governments. Although these firms have grown to great strength because of the opportunities and protection provided by the United States, they have ceased to have any real identity with (and loyalty to) America as a distinct nation. These enterprises have been a relentless and often ruthless force hollowing out the powers of the United States (as well as of other nations) and transferring these powers to international financial institutions (such as the International Monetary Fund, the World Bank, and the World Trade Organization) or to "global regimes" or "global governance" (or to no governance at all). ${ }^{8}$

We have examined three dimensions or arenas of American conservatism-economic, religious, and security-and we have seen that, from a European perspective, American conservatism was not conservative at all, but actually was a kind of classical liberalism. Insofar as American conservatism was involved in conserving anything, it was precisely this liberalism.

The three dimensions of American conservatism each had their own distinct logic. However, they also had much in common. First, each conceived of its relevant environment or condition as being relatively open and unconstrained. This meant that units operating within this environment had a good deal of leeway or freedom to do what they pleased (always recognizing, of course, that they would be bumping into other, similar, even equal units, 
and this condition would provide its own kind of constraint). Ultimately, the leeway or freedom of the units was so unconstrained that they could dissolve or disintegrate into their least common denominator, into their smallest possible element, and this of course was the individual. Individualism, therefore, was at the very core and foundation of American identity, and particularly of American conservatism. ${ }^{9}$

\section{The Golden Age and the Indian Summer of the Original American Conservatism}

For many decades after the founding of the United States, the economic, religious, and security conditions that enabled this pervasive individualism-and the pervasive classical liberalism and therefore the peculiar and paradoxical American conservatism that was defined by it-largely endured. This was particularly true of the century between the War of 1812 and the First World War. The American Civil War, which came precisely in the middle of this century, was an apparent exception, but actually it largely confirmed the distinctive American pattern, and in any event it only lasted four years. Thus, this particular American century can be seen as a sort of golden age for this peculiar American conservatism.

Again, one might have expected that the First World War would bring an end to the distinctive American conditions-it certainly brought an end to any strong and solid basis for classical liberalism in Europe itself. ${ }^{10}$ However, America's participation in the war was actually very brief (U.S. forces did not really begin combat operations until March 1918, and these were over in eight months) and with relatively few casualties (U.S. forces suffered far fewer combat fatalities than any of the other great powers-for example, only 8 percent of those of France-and even fewer combat fatalities than most of the small participants-such as those of Romania). ${ }^{11}$ Moreover, the wartime experience seemed decisively to vindicate and even enhance the strengths of both the traditional American economic system and traditional American moral principles. Consequently, when the war was over, the United States eagerly and rapidly returned to its traditional ideas and ideals, to what was seen as "normalcy" in each of the economic, religious, 
and security dimensions, and it did so under the leadership of the Republican Party, the political party that was most identified with the great project of American conservatism, that is, of conserving, and restoring, classical liberalism, including its core ideal of individualism.

However, the 1920s were not really a new golden age for American conservatism. Too many changes and challenges had recently occurred within the economic, religious, and security arenas for there to be a full restoration of the American world of the nineteenth century. Rather, the 1920 s can accurately be seen as a sort of Indian summer of that world. The decade represents a culmination of the original, and by then traditional, American conservatism, just before that conservatism would be assaulted by the economic challenges posed by the Great Depression, the religious challenges posed by secularization within the American social and cultural elites, and the security challenges posed by the Second World War.

\section{The 1930s: The Great Debacle of the Original American Conservatism}

The orderly world and Indian summer of this original American conservatism abruptly came to an end as the 1920s themselves came to an end. It collapsed under the multidimensional assaults posed by the onset of the Great Depression in 1929, the growth of secular ideas (and the growing sense that Prohibition was a failure) in the late 1920s, and the beginning of Japan's imperial expansion in Manchuria and China in 1931-1932. ${ }^{12}$ By the election of 1932, it was clear to a majority of Americans that the old conservative order had collapsed. ${ }^{13}$ Although it was not so clear that the policies of the Republican Party had been the cause of this collapse, it did seem clear that the party had not done a good job of conserving that order and that it had no convincing plan for how to restore it. The election of Franklin Roosevelt as president and of a large Democratic majority in Congress initiated a whole new era in American history, and in the history of American conservatism more particularly. Indeed, for much of the next halfcentury, it almost seemed that the history of American conservatism had itself come to an end. 
The original American conservatism did not respond well in the 1930 s to the multidimensional challenges in the economic, religious, and security arenas. Indeed, it has been widely believed ever since that it failed in each of these three great tests of that time. Consequently, American conservatism was on the defensive and on the decline for several decades. It would not begin to reviveor rather be reinvented-until the fusionist project of the early 1960s, and it would not be truly robust again until the Reagan era of the 1980s. But, as we shall discuss in the concluding sections of this chapter, this reinvented American conservatism is itself now on the defensive and on the decline. Perhaps, in its own way, reinvented American conservatism has failed the great economic, religious, and security tests of our own time.

In the course of the 1930 s, conservatives responded to the challenges by essentially splitting into two camps, and this was the case in each of the three arenas. One camp, normally the larger one, essentially abandoned the original conservative (really classical liberal) position. Most economic and social elites made this choice. They adopted instead moderate versions of the political ideology that was coming into being with Roosevelt's New Deal in economic policy, but also with greater secularism in religion and greater internationalism in foreign affairs. Although often called "liberalism," this new ideology envisioned a much larger role for the federal government in many sectors of society; it had much more in common with the Progressivism of Theodore Roosevelt and Woodrow Wilson than it had with classical liberalism. (Indeed, it would be more accurate to call this particular worldview progressivism, rather than the commonly used term of liberalism.) This camp of conservatives, therefore, was hardly conservative at all. Rather, they were merely moderate progressives.

Of course, the original conservatives had not really been conservatives either. They were merely classical liberals. It seems to be the case in America that most so-called conservatives have really been something else. This has confused not only external observers of American conservatism (be they on the European Right or on the American Left), but it has confused American conservatives as well.

However, the second camp, normally the smaller one, largely continued to adhere to the original conservative (classical liberal) 
position. This was especially the choice of many ordinary persons, particularly small businessmen and Bible-believing Protestants. Although these persons might still form the social elite in small towns, they decidedly did not form the elites in the cities and at the national level. And, step-by-step in the course of the 1930s and 1940s, they ceased to form the elite of the Republican Party. The last Republican presidential candidate to represent some version of original American conservatism was Alf Landon in 1936, and his decisive electoral defeat, even debacle, confirmed the view for most of the Republican leadership that the old conservatism could no longer win elections. For almost three decades thereafter, until the candidacy of Barry Goldwater in 1964, every Republican presidential nominee was some kind of "moderate conservative" or "liberal Republican" - and in favor of some kind of large role for the federal government in many sectors of society (these candidates were: Wendell Wilkie in 1940, Thomas Dewey in 1944 and 1948, Dwight Eisenhower in 1952 and 1956, and Richard Nixon in 1960). The similarity of the policy positions of these Republican candidates to those of their Democratic opponents caused many political commentators to refer to the Republicans as the "me-too" party.

Consequently, if one is interested in American conservatism, one will not find much interesting in the Republican Party during the period that stretched from the late 1930s to the early 1960s, or at least in its leadership and its elite. Insofar as there was a genuine American conservatism during this era, it was found within the minority camp of the Republican Party, whose geographical location was centered in the Midwestern states and whose sociological location was centered in small businessmen, Bible-believing Protestants, and traditional patriots of British or "old-stock" origin. Their principal leader for many years was Senator Robert Taft of Ohio (whom his followers called "Mr. Republican"). After his death in 1954, however, conservatives were largely bereft of any real political leader at the national level, until the emergence of Senator Barry Goldwater of Arizona (who announced his candidacy for this role with the publication of his book The Conscience of a Conservative in 1960 and who subsequently ran for president in 1964). 
The Mid-Thentieth Century: The Golden Age of American Progressivism

Thus for three decades-from the mid-1930s to the mid-1960s and from the Great Depression to the Vietnam War-American political ideas and public policies were shaped by what was sometimes called "the liberal consensus" (although it was actually a progressive one) and by its counterpart, the conservative marginalization. This era saw such epic American achievements as the recovery from the Great Depression, the winning of the Second World War (with war production largely explaining the economic recovery), the rise of the United States to superpower status, the peace and prosperity of the Eisenhower years, and the apparent taming of the business cycle (with depressions being replaced by mere recessions) by some version of Keynesian policies, be it the "military Keynesianism" of the Eisenhower administration (defense spending accounting for 10 percent of GNP, even in a time of purported peace) or the "economic fine-tuning" of the Kennedy administration. And for these achievements, progressive policies got the credit. It certainly seemed that American conservatism had nothing significant to add, or even to say.

What then explains the conservative revival that eventually occurred by the late 1970s and which took control of the U.S. government with the election of Ronald Reagan as president and of a Republican-controlled Senate in 1980? Conservative thinkers and think tanks (especially neo-conservative ones) ascribe this revival and its success (which they call "the Reagan Revolution") to their own thoughts, that is, to the philosophical and political ideas and policy proposals that they published in their journals (examples include The Public Interest, The National Review, and Commentary). Standard histories of the conservative movement give a lot of weight to such thinkers (or publicists) as Russell Kirk, William F. Buckley, James Q. Wilson, Irving Kristol, and Norman Podhoretz. ${ }^{14}$

All of this attention by conservative writers to other conservative writers (or to themselves) makes for rather tiresome reading about thinkers regarding whom most American citizens and politicians (including Republican ones) have never thought. In any event, the decisive causes for the revival-or more accurately, the reinvention-of American conservatism lay not in new 
conservative thinking, but rather in two sets of causes which were more fundamental-and which were less mental and more material. These were, first, the failures of particular progressive policies, which by the 1970s had become apparent to almost everyone, and, second, the shifts that occurred among particular components that formed the social bases of the two political parties and their associated ideological movements.

\section{The 197os: The Great Debacle of American Progressivism}

The progressive policy failures occurred in the same three arenasthe economic, the religious (by now also the moral and social), and the security-that had been the locus of the conservative failures in the 1930s.

The economic arena: Forty years after the beginning of the Great Depression, the United States and the world more generally experienced another great economic crisis, one that eventually came to be called the Great Stagflation. It was similar to the Great Depression, in that the major industrial nations suffered a significant rise in prolonged unemployment. However, the level of unemployment, although prolonged, only reached the level of previous recessions, not of the Great Depression itself. Conversely, this economic crisis was different from the Great Depression in that the major industrial nations suffered a sharp rise in prolonged inflation (with annual rates often at double-digit levels). The conjunction of the stagnation of unemployment and the inflation of currencies gave the prolonged crisis its name, the Great Stagflation. ${ }^{15}$

It was the inflation part that most alarmed middle-class populations and most confounded progressive and "moderate conservative" politicians. By the late 1960s, these politicians had fully embraced Keynesian theories about the proper way to effectively manage the economy. But although Keynesianism certainly could claim to have a solution to the problem of unemployment (which had been the central problem of the Great Depression), it had never focused upon the problem of inflation. With the onset of substantial and sustained inflation after 1968, the United States, as well as many other industrial nations, was confronted with a 
great economic challenge for which Keynesianism had no solution. Even though the problem of stagflation persisted for years, indeed throughout the 1970s, Keynesian economists were never able to develop a convincing theory of the crisis, and progressive and moderate-conservative (i.e., Democratic and Republican) political leaders were never able to implement an effective policy to tame it. This failure went a long way toward discrediting progressivism in the minds of many Americans, and particularly those in the inflation-impacted middle class.

The religious and social arena: At about the same time as the Great Stagflation and the failure of Keynesian economic policies, there was a somewhat parallel development of dilemmas within the progressive welfare state and a failure of Great Society social policies. By the mid-1970s, it had become clear that something was going wrong with these social policies, particularly with regard to American blacks. Although a minority of blacks seemed to benefit from the policies and entered the middle class (analogous to "the talented tenth" that W. E. B. Dubois had observed as early as the 1900 s), the majority of blacks remained caught in a complex of deprived backgrounds, low education, high unemployment, violent surroundings, and extremely high rates of crime. Once again, the middle-class population was alarmed, and the progressive and moderate-conservative politicians were confounded. Progressive sociologists were never able to develop a convincing theory of the problems in the black population, and progressive and moderateconservative (i.e., Democratic and Republican) political leaders were never able to implement an effective policy to solve them. This failure also went a long way toward discrediting progressivism in the minds of many Americans, and especially those in the crime-impacted middle class.

The evident failure of progressivism to address the economic problems posed by the Great Stagflation and the social problems within the black population, and indeed the direct impact that pro-black policies had upon sectors of the white population, brought about a new set of major changes in the social bases of the two political parties and their associated ideological movements. In particular, two large groups, which had long identified with the Democratic Party, shifted their votes to the conservative wing of the Republican Party. The first was Southern whites, who obviously 
saw racial issues as a top priority. The second was ethnic Catholics, some even within the working class, who paid the most direct costs for policies of school integration and affirmative action. As a result of these shifts in social bases, the progressive part of the Democratic Party became much more dependent upon and shaped by its remaining components, that is, the media, academia, and municipal-employee and teachers' unions. ${ }^{16}$

The security arena: By the late 1960s, yet another great failure of progressivism and moderate conservatism was becoming manifest. This, of course, was the Vietnam War. The U.S. military intervention in Vietnam, initiated by the Kennedy administration in 1961 and greatly expanded by the Johnson administration in 1965, certainly was an expression of such progressive ideals as internationalism (backed by military interventionism) and nationbuilding (legitimated by democratic rhetoric). And it was also an expression of moderate-conservative imperatives such as antiCommunism and containment. But by 1968, the U.S. war in Vietnam was clearly going very badly, and for this pressing problem the Johnson administration and the conventional progressives again had no convincing solution. This incapacity of progressives in the face of this great security challenge was a central factor in Lyndon Johnson's decision in March 1968 not to run for reelection that year. It was also a central factor in the election of Richard Nixon as president.

Eventually the progressives were given a second chance at security policy with the election of Jimmy Carter as president in 1976. By now, they had learned from their failure in Vietnam about the costs of military intervention and militant anti-communism, and in its first three years the Carter administration pursued a relatively passive security policy. At the same time, however, the Soviet Union had been emboldened by the U.S. failure in Indochina and by the establishment of Communist regimes in Vietnam, Cambodia, and Laos, and it soon enabled Marxist movements to gain power in a wide range of countries elsewhere. The Soviet Union and more generally Communism seemed to be on a roll, and the progressives seemed to have no convincing ideas or effective policies to meet this challenge.

The resurgent security challenge posed by the Soviet Union and communism was soon joined by a new security challenge 
posed by Iran and Islamism. The Carter administration's ineffective responses to the Islamic Revolution in Iran and to the hostage crisis at the U.S. embassy there were widely seen as a humiliating debacle for the United States. Here was yet another security challenge for which the progressives seemed to have no convincing ideas or effective policies. This double failure in the security arena completed the discrediting of progressivism in the minds of many Americans.

\section{The Late Thentieth Century: The Revival and Reinvention of American Conservatism}

Given the progressive failures across three policy arenas-adding up to progressivism's own great debacle-the way was clear for some kind of conservatism to reappear as a serious force in American history, and this did indeed occur during the 1970s. However, this kind of conservatism was not really a revival of the original or traditional American version. Rather, it was something quite different, a reinvention of American conservatism altogether, one that stretched across all three policy arenas.

The economic arena: As it happened, by the 1970s there was a body of economic ideas which claimed that it could solve the problem of inflation (and, in doing so, also the problem of unemployment). This lay in the theories of Milton Friedman and more generally of what was known as the "monetarist school." Whereas Keynes and his followers focused upon government spending and fiscal policy as the balance wheel of the economy, Friedman and his followers focused upon the money supply and monetary policy as that balance wheel. And whereas Keynesianism called upon government (and elected officials) to intervene directly in the economy through expenditures and taxes, Friedmanism called upon the central bank-which in the United States is the Federal Reserve System (and appointed officials who are largely independent of elected ones but actually quite dependent upon the executives of major banks) - merely to intervene indirectly in the economy through interest rates and the overall money supply. Friedmanism thus advocated a radical shift in the location of the economy's balance wheel and therefore in the power of those who would run it. 
Although Friedman and his followers were always talking about the virtues of the free market and of conservatism in economic affairs, their approach was not truly a free-market or originalconservative one at all. Instead, they advocated a controlled market in matters of money, credit, and finance, while advocating a free market with respect to almost everything else. And the market in money, credit, and finance was to be controlled by an oligopoly of the major banks, implemented through the Federal Reserve System (whose name made it sound like some kind of government agency, but whose reality made it more a cartel of profitmaking banks).

A truly free-market and original-conservative set of ideas about the money supply, and about the general economy, also existed in the late 1970s, and this was found in the theories of Friedrich Hayek, Ludwig von Mises, and what was called the "Austrian school." They argued that the economy, including its interest rates and money supply, should operate without any organized intervention at all, whether by government agencies or by a banker's cartel. ${ }^{17}$

During the era of Keynesian hegemony in economic affairs, both the monetarist school and the Austrian school had been marginalized in academic economics departments and among economic-policy advisors. But the failure and incapacity of Keynesianism meant that these two marginalized alternatives now had an opportunity to supercede it. A main reason why Friedmanism became the alternative that did so, rather than the ideas of Hayek and von Mises, was that the former had a large complex of economic interests (the major banks: "Wall Street") supporting it, while the latter had no such support (the only substantial interests likely to support it were small banks and small businesses: "Main Street").

The monetarist approach was adopted by the Federal Reserve System in 1979 and implemented by its chairman, Paul Volcker, in 1979-1982. Volcker's actions were indeed highly effective (although of course temporarily very painful) in bringing inflation to an end, and in 1983 the U.S. economy began a period of impressive growth that was largely sustained for almost two decades, until 2000. This success in solving the problem of inflation, while also providing for growing employment-for bringing an end to the 
Great Stagflation-gave Friedmanism an enormous boost in credibility and prestige. It now became hegemonic in academic economics departments and among economic-policy advisors, and it has held this dominant position for 30 years (1980s to 2010s) after the Great Stagflation, just as Keynesianism had been hegemonic for about 30 years (1940s to 1970s) after the Great Depression. Of course, the Friedman school has been just as insistent and effective in keeping the Austrian school marginalized (and indeed virtually unknown) as the Keynesian school had been before.

Since Friedmanism is not truly a free-market approach (despite its rhetorical claims to be so), what is its relation to American conservatism as this applies to the economic arena? It is most accurately seen as a kind of pseudo-conservatism, not as an example of the original American conservatism. This means that when the "conservative movement" and the Reagan Revolution brought about a "revival" of American conservatism, it was actually bringing about its reinvention on the economic dimension. Consequently, this most central and weighty dimension of American conservatism would not be truly conservative at all, in any real sense of the word (in either its traditional European or its traditional American meaning).

Nevertheless, the pseudo-conservatism of Friedmanism had a very good run at managing the American economy for a very long time (almost 30 years), just like the progressivism or pseudoliberalism of Keynesianism had had previously (also 30 years). However, as we shall see, the hegemony of the major banks within the hegemony of Friedmanism was a birth defect and fatal flaw that would eventually work its way out and bring about the next great economic crisis, that is, the Great Recession that began in 2007 and that continues until today.

The religious and social arena: During the long era of progressive ascendancy, which included both progressives and moderate conservatives, both Democratic and Republican elites-Biblebelieving Protestants had largely remained a component of the original-conservative minority within the Republican Party. However, they did not have any reliable and effective political vehicle, and they were marginalized in electoral policies and in public policy. Then, a number of developments in the 1970s brought about a rise in their potential influence. 
First, after several decades of political inactivity, Bible-believing Protestants were awakened and energized by particular progressive advances with regard to moral issues. The most central of these was the issue of abortion, for which a monumental milestone was the Supreme Court decision in Roe v. Wade in 1973. Just as Prohibition had been "the Great Crusade" of conservative Protestants for three generations from the 1870s to the 1920s, so Pro-Life became their great crusade for the three decades from the $1970 \mathrm{~s}$ to the 2000 s.

Second, as we have seen, the shifts in the social bases of the two political parties and their associated ideological movements, which were produced by progressive policies and which occurred in the 1970s, brought Southern whites and ethnic Catholics into the Republican Party. As it happened, each of these groups had something important in common with the Bible-believing Protestants who were already in the party. For Southern whites, this was the Protestant part (and, indeed, when Southern whites had been Democrats, many had also been among the most Bible-believing people in America). For ethnic Catholics, this was the Pro-Life part. Thus, the shifts in social bases brought about a new conservative grand alliance with respect to religious and social issues and around commonly shared "traditional moral values."

Of course, traditional conservatives had long been bereft of any credible national political leader (after the death of Robert Taft, Barry Goldwater had briefly been the closest approximation to one, and he was much more a social libertarian than a traditional moral conservative). By itself, religious or traditional moral conservatism was not going to produce a credible national political figure. However, the fusionist project of the conservative movement had laid the intellectual groundwork for uniting social conservatives with economic and security conservatives. And Ronald Reagan, "the Great Communicator," certainly had the gift of being able to speak to the different arenas of traditional conservatism, in words and concepts that they not only understood, but that they loved. It was Reagan who appeared to traditional religious and social conservatives to be, at long last, their authentic political representative and effective political vehicle. And it was he who brought them into the grand alliance of conservatives that provided the electoral base for "the Reagan Revolution." 
We have observed, however, that with regard to economic policy, the Reagan era and the following years of Republican political power did not really produce original-conservative policies, but ones that were merely pseudo-conservative. Much the same thing can be said for the social policies of the Reagan era and later Republican rule. Reagan and some other Republican leaders were excellent in their public speeches and pronouncements with respect to traditional moral values. However, when it came to implementing these values in actual legislation and practical policies, the results — after a period lasting almost three decades-have been negligible. The main benefit that traditional social conservatives have received from Republicans in the White House and in Congress has been four Supreme Court appointments-Antonin Scalia, Clarence Thomas, John Roberts, and Samuel Alito. And so, in a sense, the reinvention of American conservatism in the social arena actually produced another kind of pseudo-conservatism-or at best quasi-conservatism-one that was parallel and analogous to the pseudo-conservatism in the economic arena.

Moreover, while the Republicans were in power in the White House and in Congress, they facilitated a major change in the demographic composition of the U.S. population-and therefore in the social bases of the two political parties and their ideological movements. This was the great increase in immigrationincluding illegal immigration-from Latin America, and especially from Mexico. Of course, this increase in immigration had originated with the Immigration Act of 1965 , which can be seen as one of the progressive policies of the time, and it had steadily increased in numbers during the 1970s. However, it was during the era when reinvented conservatism was in ascendency and the Republicans were in power that the Hispanic immigration and the ensuing Hispanic births in the United States reached massive proportions. For example, in the 1980s, Hispanics accounted for 5 percent of the U.S. population; by the late 2000 s, as a group they accounted for 15 percent, surpassing the black population in numbers.

Progressives had their own ideological reasons for facilitating immigration, based first upon ideals of racial equality and human rights and then upon the ideology of multiculturalism. But why did the Republican Party—with its putative social conservatismjoin the Democratic Party in facilitating this massive demographic 
and therefore social change? The reason is that the grand alliance of reinvented conservatives were simply ordering their priorities and following the same script as the grand alliance of original conservatives had done in the nineteenth and early twentieth centuries, that other era of open immigration into the United States. That is, the economic interests of business and middle-class conservatives in cheap labor trumped the communal interests of the cultural and social conservatives.

Of course in the long run, since "demography is destiny," this new and massive demographic sector could become a new and massive voting bloc. Given the voting behavior of most previous immigrant groups and racial minorities, it seemed most probable that this Hispanic voting bloc would largely vote for the Democratic Party. However, given the hegemony of business interests in the Republican Party, it is not surprising that the short-term profit-making interests of its business constituency trumped the long-term vote-getting interests of the party itself. And so, once again, re-invented conservatism was revealed to be merely pseudoconservatism. Indeed, given the massive changes that a new Hispanic bloc could produce in American society and politics in the future, reinvented conservatism was, at least with respect to the social arena, even a kind of anti-conservatism.

The security arena: In the 1970s, a number of policy intellectuals came together to develop a systematic critique not only of the security policies of the progressive Carter administration, but also those of the preceding moderate-conservative Nixon and Ford administrations. They called themselves "neo-conservatives." These thinkers had already developed a systematic critique of progressive and moderate-conservative social policies, but by the late 1970s their principal focus was on the security arena. They were particularly alarmed about the resurgent Soviet and Communist threat and the new Iranian and Islamist threat. ${ }^{18}$

The neo-conservatives proposed a comprehensive program to revitalize U.S. security policy and to strengthen America's leadership in the world. In particular, they advocated: (1) major increases in U.S. military spending and expansion of U.S. military forces; (2) enhanced military assistance to friendly foreign governments that were threatened by Marxist or Islamist movements; (3) enhanced military assistance to insurgent movements that sought 
to overthrow Marxist regimes (this was the most innovative of the neo-conservative proposals; it would eventually be formulated as the Reagan Doctrine); and (4) renewed willingness to undertake full military interventions, that is, to employ U.S. military forces to overthrow unfriendly governments and to protect friendly ones.

With the exception of (3), these proposals merely called for a revival of previous U.S. policies and practices in the security arena. Indeed, some version of them had earlier been carried out by moderate-conservative administrations (Eisenhower and Nixon) and even by progressive ones (Truman, Kennedy, and Johnson). Even the original-conservative Republican administrations of the 1920s used such methods in dealing with countries in the Caribbean basin and Central America. However, in the era of "the Vietnam syndrome" and the unusually passive security policies of the Ford and Carter administrations, the neo-conservative proposals seemed new, fresh, and vigorous.

The neo-conservative security program was largely adopted by the Reagan administration when it came into office in 1981. As it turned out, that administration and its successor, the George H. W. Bush administration, did achieve a series of extraordinary successes in first reducing and then eliminating the Soviet threat (examples include the Soviet withdrawal from Afghanistan in early 1989, the collapse of East European Communist regimes in late 1989, the reunification of Germany on Western terms in 1990, and finally the dissolution of the Soviet Union itself in 1991). Although the actual causes of the Soviet debacle are complex and disputed, the neo-conservatives naturally claimed the credit for this historic achievement of the Reagan and Bush administrations.

There was still, however, the threat from Iran and from Islamism more generally, and this threat continued to grow at the very time that the Soviet threat was disappearing. And here, the record of the neo-conservatives and the Reagan and Bush administrations is marked by significant failures (examples: the U.S. military intervention in Lebanon in 1964 and the growing threat from Islamist terrorists in the 1980s and early 1990s). Even the apparent successes would later turn into major security problems (as with the U.S. assistance to Islamist insurgents against the Soviets in Afghanistan in the late 1980s and the U.S. victory over Saddam Hussein in Iraq in 1991). And as we shall see in a concluding section of 
this chapter, the failure of the neo-conservatives would become even more manifest when they became one of the two core groups (the other being the oil industry) shaping the security policy of the George W. Bush administration with respect to the Middle East and Islamism. When the neo-conservatives turned their attention to this region, they largely overlooked the relevant local realities and instead imposed concepts drawn from abstract ideologies that had been developed for other regions, especially for Europe. Thus, they spoke a great deal about "Islamo-fascism" and Saddam Hussein's "Stalinism" and, conversely, about the U.S. success in occupying and democratizing West Germany and Japan after the Second World War.

In what sense, then, can it be said that neo-conservatism is an authentic kind of conservatism with respect to U.S. security policies pertaining to the Middle East and Islamism? It argues for extensive U.S. military involvement, and even U.S. wars, in a region where U.S. national interests are unclear and greatly disputed, and there is little that is conservative about this. It too is more accurately described as a kind of pseudo-conservatism. And it argues for intensive U.S. political involvement to remake Middle Eastern states and Muslim societies, and there is little that is conservative about this. It is more accurately described as a kind of anti-conservatism. Overall, then, neo-conservatism is not really conservatism at all.

\section{The 2ooos: The Great Debacle of Reinvented American Conservatism}

And so, in the fullness of time (which in America seems to be after about three decades), reinvented American conservatism brought about its own great debacle, again a debacle great enough to encompass all three policy arenas.

The economic arena: The three decades when Friedmanism and the monetarist school dominated economic theory and the Federal Reserve System dominated economic policy were largely an era of impressive economic growth and prosperity. There were occasional stock market panics or business recessions (19871988, 1991-1992, 2000-2002), but overall the U.S. economy seemed to be operating so smoothly that Alan Greenspan and Ben 
Bernanke-successive chairmen of the Federal Reserve Board and archetypal exponents of the monetarist worldview-could call the era (and their own management of the economy) "the Great Moderation."

However, near the end of this era and in the aftermath of the recession of 2000-2002, some ominous developments and unhealthy distortions appeared. The economic boom that began in 2003 was based not upon new technologies and investments in productive assets (such as the information-technology boom of 1993-2000), but upon the real estate, especially the housing, sector. And soon, the housing boom became a speculative bubble, which burst in 2007 and then turned into a bust. Since banks had very heavily invested in overvalued real estate and complex securitized mortgages, the housing crisis soon metastasized into a fullblown financial crisis, and since credit and finance is the lifeblood (and in an era of monetarist and Federal Reserve hegemony, the balance wheel) of the economy as a whole, the financial crisis in turn soon metastasized into a full-blown economic crisis. Indeed, this crisis was in many ways-particularly with respect to high and prolonged unemployment - the greatest economic crisis since the Great Depression almost 80 years before, and it was soon given its own name-the Great Recession. ${ }^{19}$ It was the major factor causing the Republican Party to decisively lose the presidential and congressional elections of 2008.

It was no accident that the Great Moderation ended with a speculative bubble in housing and complicated securities. For, at the center of this era were the major profit-making banks. Throughout this period, they had relentlessly and successively lobbied government officials to reduce and remove restrictions upon banking activities that had existed ever since the New Deal and Depression-era financial legislation of the 1930s (most importantly, the Glass-Steagall Act of 1933, which limited the risk-taking activities of commercial banks). By 2000, the financial sector had succeeded in abolishing most of the New Deal legislation, and that which remained was very lightly enforced by the anti-regulation appointees of the George W. Bush administration. Then, when virtually no government restrictions remained upon their profitmaking activities, the major banks decided that they could make 
the most profit by investing in familiar and apparently solid ("real" estate) assets, rather than in innovative and apparently risky (but ultimately more productive) enterprises. This kind of decision to invest in the familiar rather than the innovative has long been characteristic behavior for very large and established banks, and it was natural that the major American banks took this path as soon as they could..$^{20}$

And so it was the very ideas, interests, and institutions that brought Friedmanism into power and presided over its long era of success which then, through their excesses, caused an economic crisis that brought their era to an end. And since these ideas, interests, and institutions have caused so much economic disruption and destruction, they can truly be said to be pseudo-conservative, rather than authentically conservative.

Of course, when Friedmanism and pseudo-conservatism was confronted with the challenges of the Great Recession, they were incapable of offering any convincing and effective solutions. In this regard, they were like their predecessors, first the free-market advocates and traditional conservatives when they were confronted with the challenges of the Great Depression and then the Keynesians and progressives when they were confronted with the challenges of the Great Stagflation. But just like these previous great economic crises were eventually addressed and solved with new economic theories and policies, so too we might hope that the current crisis will be also. But just as it took about a decade of crisis before those earlier new theories and policies at last became ascendant, we will probably be waiting for our new solutions to the current crisis for quite some time. In the meantime, despite the disruption and destruction that they have wrought, the major banks and the monetarist school continue to prevail in the making of U.S. economic policy.

The religious and social arena: Since the political representatives of reinvented conservatism produced a good deal of religious and social conservative rhetoric but negligible policy results, there were not any policy failures of reinvented conservatism in the religious and social arena comparable to those in the economic arena and contributing to its contemporary great debacle. However, the choices that reinvented conservatives made with respect 
to immigration policy from the 1980 s to the 2000 s finally matured into political consequences in 2008. In that year, Hispanics overwhelmingly (about 70 percent) voted for the Democratic Party, and they provided the margin for victory for many Democratic elected officials. Hispanics repeated this electoral role in 2012. The prospects are that this strong Hispanic identification with the Democratic Party will continue into the future, adding another large voting bloc to the Democratic base, parallel to the one that blacks have long provided to the party. (Together, these two voting blocks of the Democratic Party will greatly outweigh the only comparable voting bloc in the Republic Party, that of white Evangelicals-or, more accurately, white Bible-believing Protestants.) The recent coming into maturity of this great transformation in U.S. electoral politics has contributed a good deal to the great debacle of reinvented conservatism.

The security arena: By the late 2000s, another failure of reinvented conservatism-and particularly of neo-conservatismwas becoming manifest. This was, of course, the Iraq War, joined increasingly by a parallel failure in the Afghan War. The U.S. war in Iraq, which the George W. Bush administration had begun in 2003, was certainly an expression of neo-conservative policies such as a willingness, even eagerness, to employ U.S. military forces to overthrow unfriendly governments and to impose democracy-promotion and nation-building on foreign countries. The same had become true of the way the Bush administration conducted its war in Afghanistan, after its initially successful overthrow of the Taliban regime in late 2001.

By 2006, the Iraq War was clearly going very badly, and for this pressing problem the Bush administration and neo-conservatives deservedly got the blame. This was a major factor in the Republicans' losing control of Congress to the Democrats in 2006. Although the new counter-insurgency strategy of General David Petraeus and the military "surge" authorized by President Bush in 2007 seemed to turn the Iraq debacle around dramatically by 2008, the grueling and growing war in Afghanistan threatened a new debacle. The major cause of the Republican defeat in the 2008 presidential and congressional elections was of course the onset of the Great Recession, but the Afghan War was an additional and substantial contributing factor. 
The 2010s: American Conservatism in the Great

RECESSION

The depth, scope, and length of the current global economic crisis-greater than any economic crisis since the Great Depression-has meant that economic and fiscal issues now dominate American politics. Although issues in the religious/social and security arenas are still intensely debated, most of the focus and energy of what now passes for American conservatism is devoted to the economic arena. As we have seen, this has always been the most important arena in American conservatism, and it is now even more central and determinative than before.

The economic arena: The policy response of the George W. Bush administration to the financial crisis of 2008 was completely in keeping with the economic priorities of the reinvented, pseudoconservatism that had brought about the crisis in the first place, which is to say, massive government bailouts of large financial institutions ("Wall Street"). These bailouts were so massive that they provoked opposition from long-dormant elements within the Republican Party which represented small banks and small businesses ("Main Street"), but when directed at a Republican administration, this opposition was only brief and ineffective (for example, Congress's initial rejection of the administration's TARP plan).

However, the succeeding Obama administration also pursued economic policies which privileged large financial institutions, while not doing much that actually improved the condition of other sectors of the economy (such as unemployed workers). Moreover, the budgets of the Obama administration and the Democratic Congress resulted in a massive expansion of federal deficits and debt (an expansion that had actually begun under the preceding Bush administration and Republican Congresses). Now the small-bank and small-business elements in the Republican Party had Democratic targets to oppose, and their opposition could be more sustained and more effective. The result was the beginning of the Tea Party movement in the summer of 2009, which was able to achieve significant successes in the congressional elections of $2010 .^{21}$

The economic and fiscal thinking of the Tea Party movement had much in common with that of the original American 
conservatism, and with theorists such as Friedrich Hayek and Ludwig von Mises. It had much less in common with the economic and fiscal thinking of reinvented conservatism, and with theorists such as Friedman and the monetarists. Indeed, the thinking of the Tea Party movement was largely the same as that of the libertarian movement, which had long been a marginal element within the Republican Party.

Consequently, with respect to the economic arena, American conservatism is now split between two tendencies: (1) a partially discredited reinvented conservatism, which nevertheless continues to dominate the leadership or "establishment" of the Republican Party because it corresponds to the economic interests of the party's elites and big donors; and (2) a partially revived original conservatism, which is a significant insurgent force within the Republican Party, because it corresponds to the economic interests of much of the party's base and many of its core voters.

This split was played out in the 2012 primary elections to nominate the Republican candidate for president. From the beginning, indeed as early as 2009, the preferred candidate of the Republican leadership and elite was Mitt Romney. In the early Republican primaries (those with several candidates competing, representing the several different tendencies within the Party), Mitt Romney consistently led with respect to campaign funding and the support of most big donors, but he usually received less than 30 percent of the votes. Conversely, the Tea Party voters often preferred Ron Paul, but they recognized that he could never win the nomination; consequently, their votes were split among several different candidates other than Romney. The party leadership had early determined that their best strategy to achieve a Romney nomination was to split the anti-Romney vote among several different candidates, no one of which could achieve a majority, or perhaps even a plurality, and this strategy proved successful. The insurgent or anti-Romney candidates cancelled out each other. Romney may not have achieved majorities, but he did achieve more pluralities than anyone else, and therefore the nomination. The party leadership calculated that any disaffected Tea Party voters could be corralled into voting for Romney against President Obama in the general election. 
The religious and social arena: In contrast to the even greater dominance of economic and fiscal issues within American conservatism since 2008, religious and social issues have been pushed even further to the margins. Both the Republican Party establishment and the Tea Party movement consider religious and social issues to be at best a distraction from the central arena of economic and fiscal issues, and at worst causing an actual subtraction of votes of independents from Republican candidates; consequently, both agreed to marginalize these issues in the 2012 elections. Even such a fundamental and immediate concern of religious conservatives as homosexual marriage was given very little attention in the Republican presidential primaries. The religious conservatives did have a preferred candidate, Rick Santorum (who is a Roman Catholic, not an Evangelical Protestant), and he did score a couple of primary victories, but like the other anti-Romney candidates, he was soon overwhelmed by the Romney strategy and money. And, in the end, the marginalization of Evangelical Protestants even within the Republican Party culminated in the Romney/Ryan nominations, the first major-party president/vice-president ticket in American history that did not include a Protestant.

Meanwhile, the Hispanic percentage of the electorate continued to increase, and their votes continued to go overwhelmingly to the Democratic Party. With all of its focus upon economic and fiscal issues, the Republican Party was not able to develop a coherent and effective strategy to win over Hispanic voters in the 2012 elections. Indeed, many traditional conservatives were opposed to Hispanic immigration, and they found some voice in the Tea Party movement. This drove Hispanic voters even further away from the Republican Party. Some Republican leaders, alarmed by this development, hoped to attract Hispanic voters by having some prominent Hispanic elected official be Romney's running mate (such as Senator Marco Rubio of Florida). But the selection of Paul Ryan brought an end to even these fitful efforts to attract Hispanics.

The security arena: The security arena provides another contrast in the development of American conservatism in the 2010s. In the midst of the continuing global economic crisis, it is not surprising that security and defense issues have been less prominent than before 2008, although they have certainly remained more 
prominent than religious and social ones. What is perhaps surprising, however, is the continuing articulation of neo-conservative priorities and policies among many Republican leaders. One might have thought that neo-conservatism would have been discredited by its debacle in the Iraq and Afghan wars, but in the election year of 2012, it was just as prominent among Republican candidates for president as it had been in the George W. Bush administration, which put the United States into those wars.

The explanation for the continuing prominence of neo-conservatism in the Republican Party does not lie in the base of Republican voters. Most of these have become critical or skeptical of U.S. military interventions abroad, especially for such remote goals as nation-building and promoting democracy. In particular, the Tea Party movement has largely avoided discussion of security and defense issues, and many of its members take positions similar to those of the anti-interventionist (and anti-defense-spending) libertarian movement. Rather, the explanation lies in the Republican elite, and particularly with some of the Republican Party's big donors. These are found in both older sources of funding, such as the defense industry, and newer sources of funding, such as hedge funds, and they continue to support neo-conservative priorities and policies, particularly with respect to the Middle East.

In the early Republican primaries of 2012, the neo-conservatives' preferred presidential candidate was Newt Gingrich. Indeed, it was funding (in the amount of $\$ 15$ million) from just one big donor, Sheldon Adelson, a casino magnate, that accounted for there being a Gingrich campaign at all and for its few and brief successes..$^{22}$ When it became clear that Romney was going to win the nomination, the neo-conservative donors, including Sheldon Adelson, then threw their support to him. Romney reciprocated by appointing a large panel of advisors, most of whom were prominent neo-conservatives, on security and defense issues and by making a series of well-publicized speeches, which advocated just about every neo-conservative priority and policy. However, there is an obvious contradiction between the fiscal conservatism of a substantial majority of the Republican Party's big donors and the security neo-conservatism of a significant minority of its big donors. This contradiction came to a head during the budget 
conflicts of 2013, with fiscal conservatism largely prevailing over security neo-conservatism.

What, then, is the contemporary character of American conservatism, half a decade after the debacle of the reinvented version, brought about by the Great Recession and the ongoing global economic crisis? We will sum up the current condition of the conservative coalition in its three component arenas.

In the economic arena, conservatism continues to be dominated and defined by the same kind of big-business, especially bigbank, priorities and policies that have been dominant for many decades. The greatly increased influence in the Republican Party of big donors on its candidates for public office has even strengthened this domination in recent years. ${ }^{23}$ But the Party also continues to articulate the rhetoric of the original, free-market conservatism, and this has been enough to retain its small-business and independent-proprietor base among voters. This base has even been strengthened in recent years by the energy and activism of the Tea Party movement, which on economic issues adheres to original-conservative values. In short, with regard to the economic arena, American conservatism is now characterized in its rhetoric by the values of original conservatism-supported by a steady or even strengthened mass base of voters-and in its reality by the priorities and policies of what we have called reinvented conservatism-supported by a steady or even strengthened elite source of donors.

In the religious and social arena, however, the picture is very different. This kind of conservatism is today much weaker and more marginalized than it was only a few years ago. First, there are now very few big donors supporting the electoral campaigns of religious and social conservatives (the only prominent exception in the 2012 elections was a billionaire investor, Foster Friese, who provided the principal financial backing for Rick Santorum). And there has also been a substantial decrease in the number of voters who count religious and social issues as their chief concern when deciding for whom to vote. Moreover, the Republican Party can always be confident that this shrinking-but still essential-part of its electoral base will continue to cast its votes, however unenthusiastically, for Republican candidates and not for Democratic 
ones. With a very small donor elite and a shrinking and subordinate voter base, it is not surprising that religious and social conservatives are now only a weak and subordinated component within today's American conservatism.

Finally, in the security arena, the picture is again different, a kind of mixture of the contrasting situations in the other two arenas. First, although the number of big donors who prioritize security issues is much smaller than those who prioritize economic ones, their donations have been sufficient to buy the security priorities of Republican candidates, at least until the recent budget crises and resulting constraints on military spending. These priorities have been those of neo-conservatism, not the original ("realist" in current terminology) conservatism; in fact, today, there are virtually no big donors who support realist conservatives as candidates for public office. When we turn from the donor elite to the voter base, however, the situation is reversed. There are very few voters who actually put neo-conservative security priorities and policies (such as U.S. military interventions and democracy promotion abroad) as their chief concern when deciding for whom to vote. Although there are a small number of voters who do make security issues their top concern, the large majority of these actually adhere to realist-conservative security priorities and policies (for example, a strong military to defend America itself).

\section{Whither American Conservatism? \\ Toward Yet Another Reinvention}

By itself, this review of the various components of the contemporary conservative coalition would suggest that the electoral prospects for the Republican Party in the future are rather poor. There is a well-funded and well-mobilized base for economic and fiscal conservatism, but although this base is strong, it is narrow. Probably no more than 30 percent of the national electorate now votes the way they do because they hold conservative economic and fiscal values, and this is at a time of pronounced economic and fiscal crisis. Of course, within particular congressional districts and particular states, this percentage will be higher, and this will enable economic and fiscal conservatives-when they can make alliances with large numbers of religious/social or security/patriotic 
conservatives - to win elections to the U.S. House of Representatives (and even to win a majority) or to the U.S. Senate (but where they are unlikely to win a majority). But in general the prospects for conservatives to win presidential elections are doubtful. It is possible, then, that the great debacle of reinvented conservatism in the 2010s will have consequences for American conservatism and the Republican Party similar to those that followed the original great debacle of original conservatism in the 1930s. That is, American conservatism already will have entered into an era where it will mostly be a political minority, while some new version of American progressivism will be in political ascendency.

Of course, most Republican politicians are well aware of these prospects, and they cannot be expected to just passively accept the implications. Rather, we would expect that they will seek to bring about yet another reinvention of American conservatism, a new version, which would provide a broader and stronger base for the Republican Party than the current narrow, incoherent, and withered version. As we have seen, both the original and the reinvented versions of American conservatism were based upon a particular coalition of distinct social components, and so too will be any new reinvention. What might the new social base and new version of conservatism look like, given the electoral realities-based upon the economic and social, but also demographic realities-of the 2010s, and beyond? And here, through a glass darkly, we may glimpse the increasing significance of both race and gender.

The potential role of racial identity: Racial issues, in the form of slavery and the Civil War, were obviously at the origin of the Republican Party and in its ascendency during its first 70 years. However, the Party was never seen as the white party. On the contrary, where blacks were able to vote, they generally voted Republican. It was the Democratic Party in the South (in the once-Confederate states) that was seen, and accurately so, as the white party. More broadly, after the Civil War, the original American conservatism, while neglectful of the interests of black people, did not include white racial identity as an important component, even in its social or cultural dimensions.

However, the coming of the Civil Rights Movement of the 1950s and 1960s-and especially the Civil Rights Act of 1964 and the Voting Rights Act of 1965-brought about a new racial reality in 
American partisan politics and a reversal of the racial identities of the Republican and Democratic parties. By the late 1960s, blacks were overwhelmingly voting for the Democratic Party, and whites in the South were largely voting for the Republican Party. Indeed, with their "Southern strategy," Republican leaders made it a major objective to have Southern whites see the Republican Party as the white party. In the South, this new racial and partisan reality has only become more pronounced during the ensuing half-century.

In the rest of America, however, Republican leaders have generally tried to avoid a racial identity being attached to the Party. Rather, as we have seen, they have emphasized economic/fiscal, religious/social, and security/patriotic issues and identities. And what has been true of the Republican Party has been even more true of the reinvented conservative movement. None of the major components of reinvented conservatism have provided any acceptance or even acknowledgment of racial issues and identity as being legitimate. The only exception is in the social arena, where many social and cultural conservatives have criticized affirmativeaction policies that have explicitly and directly given preferences to blacks and Hispanics.

These policies seemed to many to be in obvious contradiction to all the language and legislation of the Civil Rights Movement about prohibiting discrimination based on race and about equal rights for all, and it provoked a good deal of resentment-and even delegitimization of the federal government-among many whites. In recent years, therefore, progressives have developed an alternative way of constructing public policies in order to give substantial assistance to blacks and Hispanics. Since a much larger proportion of these two groups is poor, in comparison with whites (and also with Asian Americans), policies that give substantial assistance to poor people will implicitly and indirectly also give such assistance to blacks and Hispanics. There have been at least three major areas where such policies have been implemented in recent years: (1) housing ownership; (2) economic stimulus; and (3) medical care.

There is therefore a growing consciousness among whites, especially among older ones, that Democratic programs not only benefit the poor at the expense of the middle class, but that they benefit blacks and Hispanics at the expense of whites. This consciousness 
is heightened by current economic realities, because government policies to bring about redistribution of monies from a stagnant or shrinking economic pie impose obvious and painful costs upon the middle class. Changing demographic realities also heighten this consciousness, because the black and Hispanic portion of the American population is steadily increasing, with these two groups already accounting for a majority of births in the United States each year.

Since the conventional identities of Republican voters-be they the identities of either original conservatism or reinvented conservatism-now issue in a voting base that is too narrow and withered to win most presidential and senatorial elections, the Republican Party leadership has to think about how to expand that base, and that probably means adding groups with new identities or ones that are redefined. In particular, the Republican establishment is now trying to somehow persuade many more Hispanics (73 percent of whom voted for Obama in the 2012 presidential election) to vote Republican in the future. However, there are formidable sociological and political obstacles standing in the way of this establishment Hispanic project.

An alternative path for the Republican Party in expanding its electoral base leads from the South to the rest of America, that is, from the Republicans being the white party in the South to the Republicans being the white party in America as a whole. In the 2012 presidential election Romney got 60 percent of the white vote, while Obama received only 38 percent. However, the Republican establishment knows how dangerous and destructive it would be to have an American party system defined and divided along racial lines, even if not explicitly or overtly so, and they are reluctant to take this path.

These considerations lead to a prospective realignment-or rather a sharpening of the current alignment-of the American party system along the following lines: The core voting groups for the progressive coalition and the Democratic Party are (1) blacks; (2) Hispanics; and (3) workers in the public sector. Conversely, the core voting groups for the conservative coalition and the Republican Party are (1) economic and fiscal conservatives; (2) Evangelical or Bible-believing Protestants; and (3) white male workers in the private sector. 
The potential role of gender identity: Of course, in this alignment there remains one immense independent or swing group, and that is white women. A substantial majority of white women now vote for Democratic candidates, with economic issues being primary for working-class women and social issues being primary for middle-class women. If these women continue to vote for the Democratic Party in the future, the prospects for the Republican Party to win most presidential and senatorial elections will remain bleak. However, it is also the case that although a substantial majority of single women vote for Democratic candidates, a significant majority of married women vote for Republican ones. This suggests that if the Republican Party can find a way to enhance its appeal to married women, perhaps with policies that genuinely support families, it might be able to strengthen its electoral base.

In our long review of the history of American conservatism, we have seen it appeal over the decades and in successive versions to a wide array of different groups and interests. But neither original conservatism nor reinvented conservatism ever had much to appeal to women, if they saw their principal identity to be as women. The same remains true of the weakened movement that now passes for American conservatism and of the Republican Party that is its institutional expression. It will only be if the conservatives and the Republicans can convince large numbers of American women, and particularly married women, that their principal concern must be to conserve something important to them that American conservatism will have a future.

\section{NOTES}

1. Patrick Allitt, The Conservatives: Ideas and Personalities Throughout American History (New Haven, CT: Yale University Press, 2009), 191-266; Paul Edward Gottfried, Conservatism in America: Making Sense of the American Right (New York: Palgrave, 2007).

2. Daniel Bell, The Cultural Contradictions of Capitalism (New York: Basic, 1976).

3. Bruce Mazlish, Nayan Chanda, and Kenneth Weisbrode, eds., The Paradox of a Global USA (Stanford, CA: Stanford University Press, 2007). 